\title{
REFLECTIONS ON THE REURBANISM PARADIGM: RE-WEAVING THE URBAN FABRIC FOR URBAN REGENERATION AND RENEWAL
}

\author{
Tigran HaAs, Ryan Locke \\ School of Architecture and the Built Environment, KTH Royal Institute of Technology, Stockholm, Sweden
}

Manuscript received: September 19, 2018

Revised version: October 23, 2018

\begin{abstract}
HAAs T., LoCKE R., 2018. Reflections on the ReUrbanism paradigm: Re-weaving the urban fabric for urban regeneration and renewal. Quaestiones Geographicae 37(4), Bogucki Wydawnictwo Naukowe, Poznań, pp. 5-21. 2 tables, 7 figs.

ABSTRACT: Within the realm of contemporary urban design theory and practice, a number of authors have conceptualised the trends and processes of city development and planning into a series of urbanisms. This discussion essay examines the overall tenets of the 'ReUrbanism paradigm', a paradigm that has long been present in city planning and development but has received limited analysis and criticism and has not gained a more integrated position within the professional and academic worlds. This paper continues a paradigm development outline, leaning on the characteristics of other urbanisms in order to develop and provide a frame of reference and to contribute to the ongoing build-up of taxonomies about the trajectory of contemporary urban design thought. Focusing on the American representative case of Detroit, the authors of this paper argue for a better understanding of this urban regeneration paradigm, which they characterise as a rational urban planning \& design approach in the contemporary age of inner city renewal.
\end{abstract}

KEY WORDS: urbanism, urban design, urban paradigms, urban decline, urban regeneration

Corresponding author: Tigran Haas, Center for the Future of Places (CFP), KTH Royal Institute of Technology, Drottning Kristinas väg 30, Entré Plan, SE-100 44 Stockholm, Sweden; e-mail: tigran.haas@abe.kth.se

\section{Introduction}

Interest in urbanism and cities has exploded in the past 25 years. Urban-isms of many kinds have entered the scene of practice and academia, public debate, politics, media and writings. Some academic writers and practitioners have tried to conceptualise the planning, design and development trends and processes in cities into a series of urbanisms. A structured outline or framework of their characteristics provides a frame of reference and even a possible taxonomy for debates about the current condition of cities and thoughts about possible urban design futures. Most of these urbanisms are manifested through various publications that carry their titles and are often exclaimed via academic or professional conferences and exhibitions. Each one of these "paradigms" (i.e. sustainable, post, new, landscape, everyday) are staking out specific claims and views on the urban realm, theoretically and practically, often attached to and reflective of, broader social, cultural and political issues at hand. The differences in these "isms" are fundamental, consistent, systemic and deep. Cynically one could turn to Rem Koolhaas, where he urges architects and urban designers and planners to at least find new terminologies if they are not able to produce new theories. This recent explosion of "isms" could be seen and treated as "a manifestation of this thinking and endeavour, an attempt to reach out to the demands of the rapidly 
changing society" (Dongsei 2014). Rem Koolhaas further advocates for new words in describing the city: "If we cannot produce new theory - and it is undeniably not an easy task - we could at least find new words... I noticed how Saskia Sassen introduced the word 'cityness' and how that word, has immediately been picked up. This shows there is huge eagerness and huge needs for new words" (Koolhaas 2007: 320). The rediscovery and reformulation of a discipline of urban design involves both defining urbanism as the field in which this practice operates, and a matter of authorising this practice as something that professionals do. Urbanism is broadly defined as the study of cities (their urban and social change), but different fields concentrate on different aspects. In architecture and urban planning, the urban form, structure, and content are the focus. One reason for the growth of interest in urbanism in general is that in post-industrial, global society, many view the human habitat as problematic. The focus on urbanism characterises contemporary urban conditions that are normative in their implications, often reflecting critical principles, and oriented toward defining urbanism in terms of intentional interventions that are often reflective of normative assumptions. The normative "what a good and livable city looks like" - aspect to the study of urbanism, and scholarship is very often focused on the need to find a new way of looking at, and resolving, how humans are supposed to create 'good' (human scale) and sustainable urban places.

A number of theories, approaches, paradigms and ideologies have influenced the contemporary practice of urban planning \& design and those effects can be seen in the form of our built environments. We base our discourse on the current urban planning and design literature, on major urban regeneration projects and foremostly on debates in urbanism, including the Michigan Debates in Urbanism (2004), Future of Urbanism (2010) in Ann Arbour, Michigan, Territories of Urbanism at Harvard (2010) and Tendencies in Urbanism in Stockholm (2015) and Gothenburg (2016) that combine public input and participation, engaged debate and polemics, the dissection of different elements of urbanism, as well as discussion of opposing views, different positions, the newest ideas and intellectual gravitas with significant contributions to the field.
Dominant ideals within today's urban planning and urban design discourse have been examined and defined in various ways - as territories of urban design (Krieger 2006), urban design force fields (Fraker 2007), integrated paradigms in urbanism (Kelbaugh 2007), urbanist cultures and approaches to city-making (Talen 2005), new directions in planning theory (Fainstein 2000), four urbanisms (Schwarzer 2000) typologies of urban design (Cuthbert 2006), opportunity urbanism (Kotkin 2007), city design modernist, traditional, green, and systems perspectives (Barnett 2011), five ideals in urban planning \& design (Olsson, Haas 2014) and plural urbanism (Ryan 2017). Haas and Olsson (2013) argue that five leading ideals/paradigms/trends that stand out clearly in international practice and current academic urban design discourse are New Urbanism, Post Urbanism, Green Urbanism, Re-Urbanism, and Everyday Urbanism.

The discussion through this reflective and analytical essay examines for the first time the overall tenets of the "ReUrbanism" paradigm (ReUrbanism as branded in the US and, or Re:Urbanism in the UK), both conceptually, and what it looks like through practice, by examining its overlaps and oppositions, approaches and modalities, strengths and weaknesses with a light reflection on the emblematic American representative case of Detroit, Michigan. We contend, in the same vein as Kelbaugh (2007) has done in Three Urbanisms, that this paradigm, or ideal, is basic and somewhat inevitable, having its merits and demerits, being unavoidably present at this point in time of the evolution of our cities. It is also a paradigm that could highlight issues and debates within city marketing, place branding and place-making schemes that are an integral part of new urban economic geographies; issues central to current debates around urban design theory and practice. From the aforementioned, it is evident that a number of scholars have conceptualised the trends and processes of city development and planning into a series of proliferating urbanisms. This is all done in the hope of adumbrating an outline of a paradigm that has long been present in city planning and development but has not gained a proper and more integrated position and has instead received limited analysis and criticism in the professional and academic worlds. 


\section{ReUrbanism and the implications for urban planning and design}

In setting up his discussion of the 'fifth migration', Fishman (2005) points out that Lewis Mumford was correct in his prediction that in the latter half of the 20th century the urban development trend would be dominated by a 'fourth migration', in which the central cities in the United States would largely be hollowed out as populations moved to the suburbs. Fishman's 'fifth migration' in 2005 was an identification of the opposite trend, the repopulation of central cities, described through four sub-trends or "four variations on the theme of reurbanism": "downtown reurbanism, immigrant reurbanism, Black reurbanism, White middle-class reurbanism" (2005: 361). This opens up for the theme of ReUrbanism, that is, the rediscovery of density, concentration, and what Mumford termed "disciplined cooperation and municipal coordination" (1968: 132) as positive values in American urbanism in a time of ongoing re-urbanisation of declining central city districts across the USA, and beyond to the global context.

A term stemming from academic urban design discourse, first coined by Robert Fishman, ReUrbanism (capitalised differently) according to Kelbaugh (in Strickland 2005: 9) "describes the positive redevelopment and revitalisation of American cities that is now happening piecemeal - the loft conversions, the in-town malls, the art museums, the concert halls, and sports arenas. It might also be called old urbanism or simply urbanism (to be done with all the prefixes)." It has to be mentioned that the US National Trust for Historic Preservation uses and has a different take on the term 'ReUrbanism', but there it refers to the fact that building reuse (older buildings are a key and irreplaceable component of sustainable future) encourages economic growth and stimulates vibrant communities, which in some elements is not that far from the mainstream understanding. According to the UK version of Re:Urbanism (written differently again),

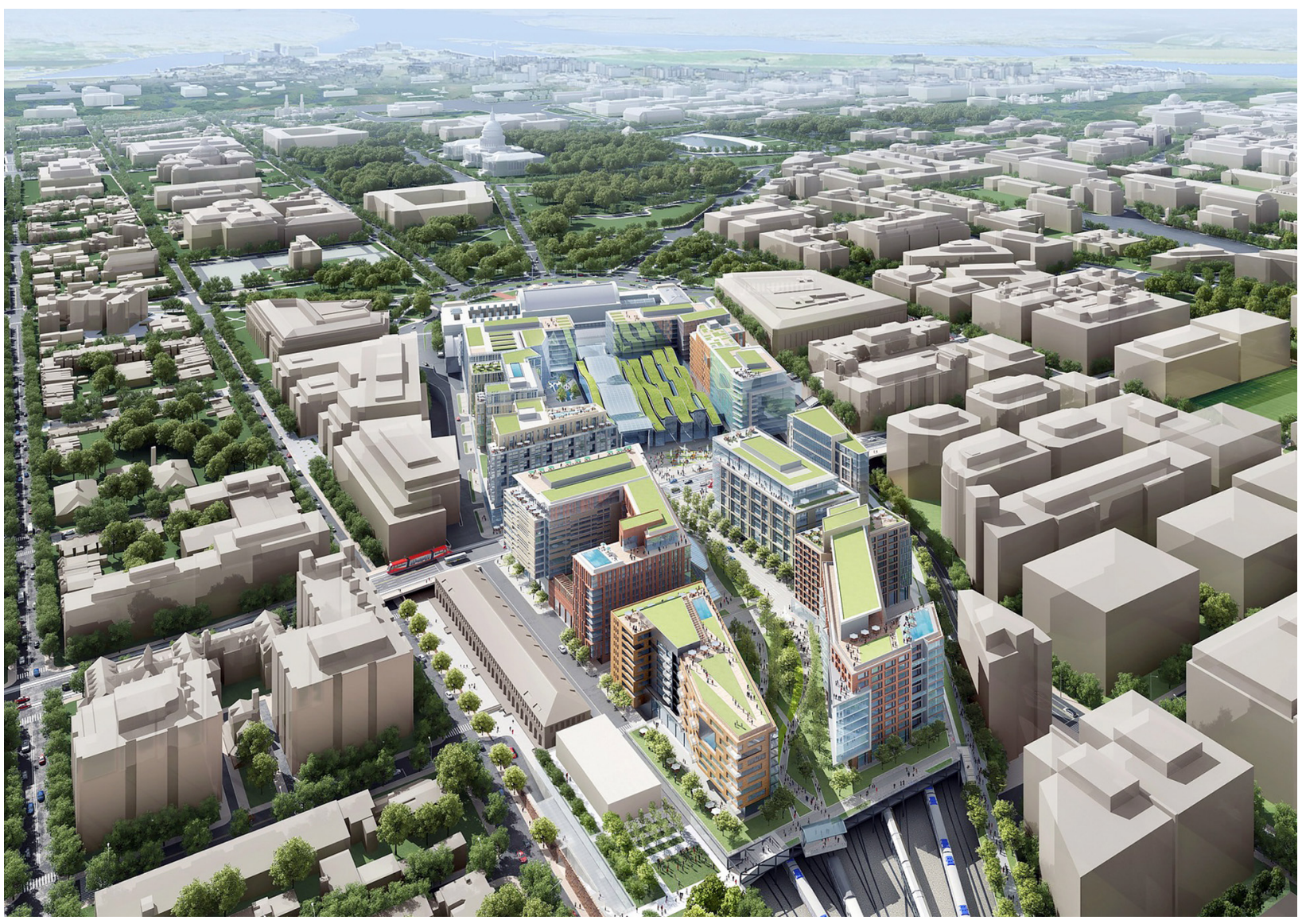

Fig. 1. Vision of Burnham Place Union Station, Washington DC. Courtesy of/Credit Akridge and Shalom Baranes Associates-Architects. 


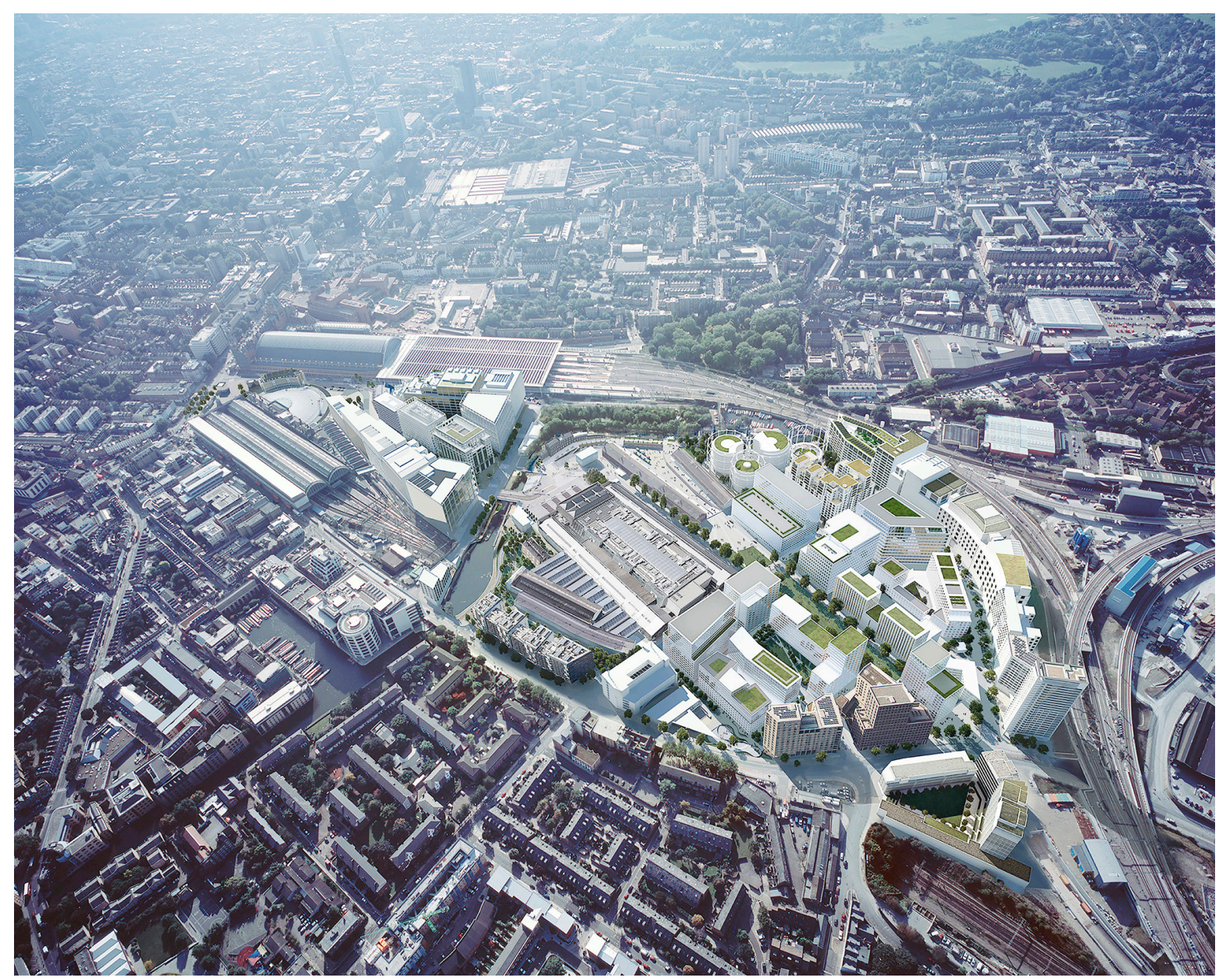

Fig. 2. King's Cross is a mixed-use, urban regeneration project in central London (KCCLP). Courtesy of RUNDQUIST ARKITEKTER AB.

urban designers have to understand complex connections throughout the urban fabric while being sensitive to context and resources at the local level as a prerequisite of their intervention (Campbell, Cowan 2002). Building on these previous descriptions, we see ReUrbanism as a rational urban planning and design approach where the city is seen as an addition or complement to the constant urban fabric within existing building stock, where it produces density and stable conditions throughout the space enabling a complex set of spaces to come together in a contextualised, programmatic and complete manner.

ReUrbanism posits a contemporary, unpretentious, at times dull but necessary 'city language', which to a large extent has been rarely discussed in urban planning and design, that is, in our culture anchored on basic urban principles. The experience of urban environments is largely determined by how understandable this 'language' is. For the sense of meaning of the city, identity, attachment and orientation - the context of the environment and the area's internal structure, how that is structured, how easy or difficult wayfinding is within? The identity of the built environment has to do with the character of the site, its historical and structural context, how the design relates to the particular nature and links the surroundings, but also with the formal qualities, regardless of the situation and the surroundings. One question is whether the reproduction of certain urban forms irrespective of the processes that generated them in the past can be validated by other means.

ReUrbanism is certainly a global phenomenon as projects such as the Hagastaden/ North Station in Stockholm, Burnham Place Union Station, Washington DC, King's Cross in London, Cape Town Station Precinct, Msheireb Downtown Doha, The Fuzhou mixed-use project 


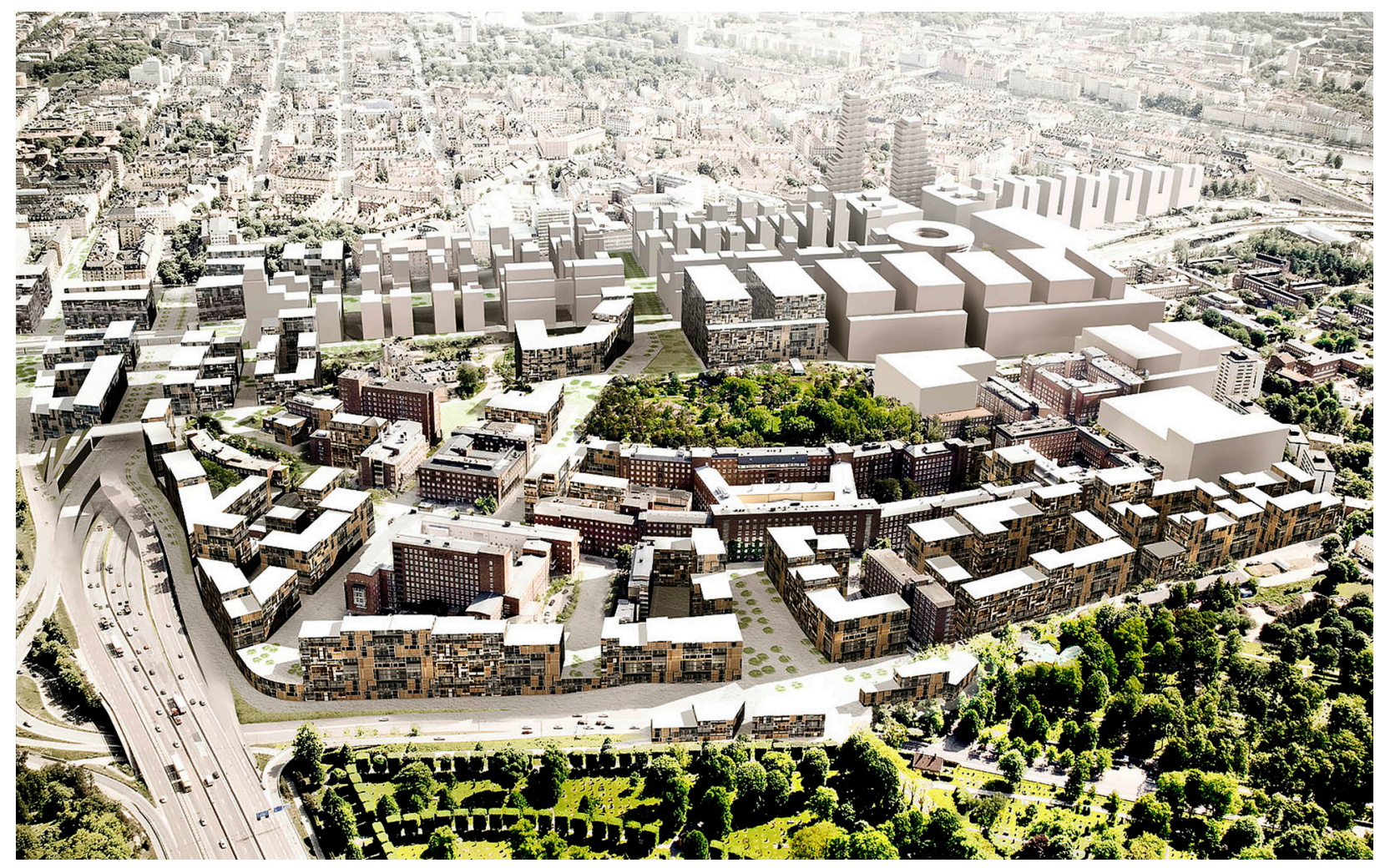

Fig. 3. Vision and imagery of Stockholm's Norra Hagastaden. Courtesy of RUNDQUIST ARKITEKTER AB.

in China, UniCredit Bank Austria Campus and The Erste Bank Campus in Vienna and many others of its kind. All projects rest on the same premise: projects include massive square meters of residential areas, commercial and office areas, and other supporting facilities, such as parking, shopping, sports, schools, higher order social facilities, expanded multi-modal stations, cultural attractions, green areas, and even world-leading research in forms of either clusters, innovation districts, living labs or connections to business improvement districts (Figs 1-3). Architecture is seen as a medium that fits smoothly into the historic and natural spatial context of the city. Using retail to remake urban mixed-use environments is also seen as a possible anchor in this paradigm, which makes it a market urbanism variance. Finally all projects are strongly anchored to transit oriented development plus office concepts are designed to cater for a new corporate culture.

The design and planning concept, especially in the context of urban regeneration and renewal comes from the urban context of the surroundings; attempting to bring the compact, dense, organic and dynamic city spaces into one project, creating a representative landmark through a design of spaces and buildings that is a reinterpretation of existing city spaces and places. Usually the sub-intent of ReUrbanism in all these cases is to create a new neighbourhood (feeling-genius loci) that will fill a gap in the urban fabric of a city. ReUrbanism is always a collaborative project between leading city actors, strong planning offices or individuals, real estate firms and real estate and business strong figures (moguls) with a long perspective in mind. All this point to a city in transition, a city in the process of remaking and reweaving disrupted urban fabrics - with the potential to significantly change the spatial form of the city and the neighbourhoods. For these reasons, later in the paper we will explore the case of central Detroit where vacant and underutilised urban land has been converted into such a development.

\section{ReUrbanism as place-making through re-weaving of the urban fabric}

Taking into account three diametrically opposed dominating paradigms today in city planning and design, New, Re- and Post-Urbanism, it is necessary to look at how they may shape the 
future, not simply explain the past. Even if they have different views on the present and future form of the city and are at odds with each other, all three combined produce a complete picture of urbanism. It should also be pointed out that ReUrbanism is sometimes known or equated with urban renewal, urban resurgence, urban regeneration and/or urban revival; showing up as a theme across a wide variety of issues found in academic research, think-tank policy and professional urban practice to everyday city development and popular urban planning and design discussions (Bitter, Krause 2012). Another critical issue of ReUrbanism is grounded in the understanding of the ongoing urban renaissance/revival/repair; ReUrbanism can be seen as a broader phenomenon of 'place-making', which allows us to point out the effects of power within the production of space beyond processes of gentrification and segregation that also come into play. Which distribution of power, top-down or bottom-up, is most likely to lead to positive urbanity, remains an open issue, one that ReUrbanism or any other leading paradigm, such as New and/or Post Urbanism cannot solve alone.

The conception of urbanism is focused on tradition because it is about the continuity of the process over time, not just about nostalgic recovery of a lost past. To the extent that urbanism is "the work of many hands," and that it is a matter of trying to "heal" the city (Alexander 1987, in Mahy 1987), ReUrbanism does not shape communities through reuse or historic preservation (as New Urbanism might) nor does it create spectacular Starchitecture decontextualised by myriad repetitions (as Post Urbanism does), leaving spaces for an open free interpretation and disassembly (as Everyday Urbanism would); therefore it posits itself between New Urbanism and Post Urbanism, acquiring elements of both and integrating a sustainable urbanism approach in the form of density, walkability, transport oriented development and materials. The new urbanists work to revive the organic quality of urbanism as something that happens over time, the work of many hands. The metaphor of re-weaving is about repairing an artifact rather than reviving a process. It is as if the city were a tapestry that has been torn or worn in spots, and the task of the urban designer (in connection with planning) is to repair those gaps in the fabric. This is different from Post Urbanism in the sense that Post Urbanism suggests that basically the age of urbanism is simply over. All we can do is take advantage of opportunities to fill in the gaps, and do so in a way that confronts and recognises the current conditions of fragmentation. In this sense, ReUrbanism is positioned between an organic healing of urbanism as a coherent process (as in New Urbanism, at its most ambitious and principled) and Post Urbanism (which is really more like old-school urban renewal). The comparison with Post, Re, New Urbanism highlights the distinctive position of ReUrbanism while illuminating the key dimensions of ReUrbanism.

What ReUrbanism tries to do is to articulate a position for projects and urban design interventions that don't just renew but repair the urban fabric. This involves efforts to reweave the holes in the urban tapestry created by either the post-industrial decay of urban infrastructure, or the economic restructuring that goes with deindustrialisation and globalisation. Whereas "renewal" is abstracted, re-weaving is responsive and responsible to the broader urban context. At times, this approach resembles more of sea patchwork than visionary urbanism in the sense of a systemic/holistic view of how the city should be structured and understood. Understanding of cities as parts of a spatial structure with their anchored dimension through sequence of places, or as an 'urban fabric' is crucial for ReUrbanists, but not at the expense of individualistic interpretations of past, contemporary and present urban forms. ReUrbanism projects are almost solely situated in central or prime locations of the city leaning on the existing elements of fabric and place formation in order to complete or adapt to the elements and density of the present.

Shaping and composing a city in the way of ReUrbanism is an art that combines the architecture and planning through urban design in ways of continuity, renewal, repair, stability and respect for place. Through the essential elements of the urban form and the vocabulary, ReUrbanists try to repair and reweave the city. They also bring a necessary but at times insufficient sensitivity to the history and culture of the place via urban density and not as much via architectural aesthetics. As ReUrbanism is primarily a formalistic city-building art, one concerned with or characterised by rigorous adherence to recognised forms, urban 
Table 1. ReUrbanism reflected via other top dominating paradigms, that of New and Post Urbanism.

\begin{tabular}{|c|c|c|c|}
\hline & New Urbanism & Post Urbanism & ReUrbanism \\
\hline $\begin{array}{l}\text { view on the public } \\
\text { realm (space and } \\
\text { place) }\end{array}$ & $\begin{array}{l}\text { community life over } \\
\text { public life (normalised } \\
\text { without external 'out- } \\
\text { side' influence) }\end{array}$ & $\begin{array}{l}\text { spaces with multiple } \\
\text { characters, surrounded by } \\
\text { transformative urbanism and } \\
\text { architecture of the high- } \\
\text { est-order }\end{array}$ & $\begin{array}{l}\text { understanding of cities as parts } \\
\text { of spatial structure with their } \\
\text { anchored dimension through } \\
\text { sequence of places }\end{array}$ \\
\hline $\begin{array}{l}\text { static and dynamic } \\
\text { processes in space }\end{array}$ & $\begin{array}{l}\text { community familiarity } \\
\text { and shared values in } \\
\text { dense traditional urban } \\
\text { form and composition }\end{array}$ & $\begin{array}{l}\text { continual transformations } \\
\text { and mutations for globalised } \\
\text { and nomadic processes } \\
\text { and habitations with mixed } \\
\text { cultures }\end{array}$ & $\begin{array}{l}\text { contemporary urban design and } \\
\text { architecture with contextualised } \\
\text { understanding of historical prec- } \\
\text { edents but also of modernity }\end{array}$ \\
\hline $\begin{array}{l}\text { spatial and social } \\
\text { dimensions }\end{array}$ & $\begin{array}{l}\text { 3rd places, civic values, } \\
\text { and mixed use and com- } \\
\text { position especially in the } \\
\text { neighbourhoods }\end{array}$ & $\begin{array}{l}\text { digital and media places and } \\
\text { multiple levels of contact } \\
\text { through iconic buildings }\end{array}$ & $\begin{array}{l}\text { prescribed places of gathering, } \\
\text { transport links and programed } \\
\text { compositions on the urban scale }\end{array}$ \\
\hline $\begin{array}{l}\text { market forces and real } \\
\text { estate development }\end{array}$ & $\begin{array}{l}\text { human scale oriented } \\
\text { urban and suburban } \\
\text { neighbourhoods with } \\
\text { civic anchor centres, mar- } \\
\text { ket demand driven }\end{array}$ & $\begin{array}{l}\text { city branding, place market- } \\
\text { ing, decontextualised objects } \\
\text { with highest real estate order } \\
\& \text { market driven }\end{array}$ & $\begin{array}{l}\text { high density, compact city de- } \\
\text { velopment, programmatic forms } \\
\text { and compositions, city branding } \\
\text { on large scale market driven }\end{array}$ \\
\hline $\begin{array}{l}\text { role and character of } \\
\text { civic spaces }\end{array}$ & $\begin{array}{l}\text { dense and urban places } \\
\text { with traditional places } \\
\text { and images }\end{array}$ & $\begin{array}{l}\text { places of expressions with } \\
\text { flowing spaces and urban } \\
\text { equivocalness }\end{array}$ & $\begin{array}{l}\text { private use and public use - clear } \\
\text { distinction with modern images }\end{array}$ \\
\hline $\begin{array}{l}\text { dominant elements of } \\
\text { urbanism }\end{array}$ & $\begin{array}{l}\text { neighbourhoods given } \\
\text { more weight than the } \\
\text { public realm }\end{array}$ & $\begin{array}{l}\text { weight given to architecture } \\
\text { and spaces in between }\end{array}$ & $\begin{array}{l}\text { equal weight to all the elements } \\
\text { of urbanism in the composition }\end{array}$ \\
\hline
\end{tabular}

Source: own study.

forms are the essential urban elements and constituent elements of a city's fabric. If you take that away, the idea, vision, structure - city - falls apart. Dealing with an organised complexity of the city, where all ideas have equal standing, is the ultimate challenge of every master planner, urbanist, or urban designer. On the other hand, ReUrbanism is not New Urbanism and such projects suffer from the absence of an unbroken, well designed and understandable system of streets, or the real public realm. According to Gehl (2010), the planning and designing of public space is in fact the definitive basic foundation to achieve the feel and urban design spirit that we experience.

The ReUrbanism trend/ideal/paradigm is presented in a taxonomic table juxtaposed to six selected elements of urban planning and design (Table 1). In terms of a critique of ReUrbanism, a number of issues can be drawn out to the surface. While plans done under the umbrella of this 'paradigm' can be delicate and subtle urban design gestures with sensitivity on multiple levels, the architecture can be disappointing, formalistic and at times dreary. All the urbanisms we mentioned before stand out as those that lean towards a classification of development of an urbanism taxonomy. ReUrbanism, in that manner, is a paradigm that positions itself and corresponds to a need for a design vocabulary and stable-form platform in order to repair and strengthen the fabric of our towns and cities. In terms of individuals, it is represented in the image of urbanists with deep sensitivity for the totality of the city structure with urbanity in their DNA. They are not individual specialists or starchitects that are designing urban spaces separately from each other. Their philosophy and way of thinking about urban design is a formalistic action to promote the vitality, liveability, and physical character of cities (Table 1).

\section{Detroit ReUrbanism}

Detroit is located within the "Rust-Belt" region of the United States, and along with other cities in this region has been famously characterised as a shrinking city, a condition characterised by: loss of jobs, white flight, suburban expansion, loss of the population, and loss of tax base (Wiechmann, Pallagst 2012). In the last 60 years, Detroit has lost $60 \%$ of its population (Neill 2015). 

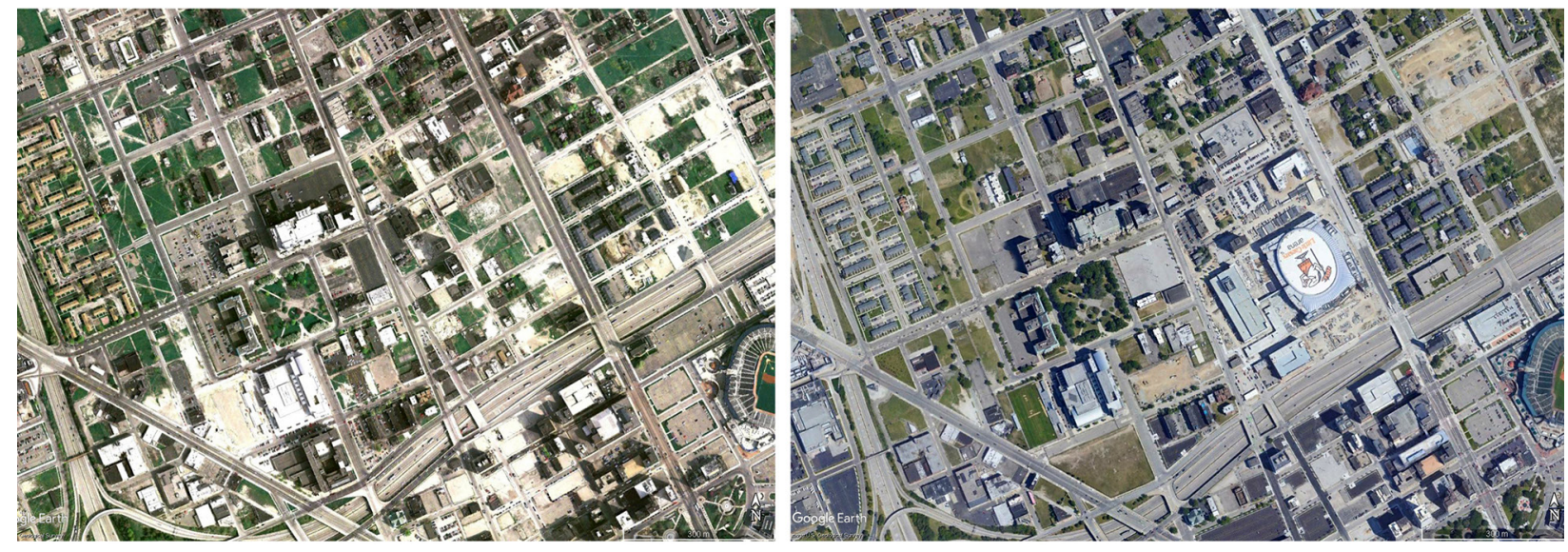

Fig. 4. Focus area of central Detroit, USA. Left, 2005. Right, 2017.

Images courtesy of Google Maps 2005, 2017.

Detroit is not alone in this situation, reflecting this loss of the population. According to Hackworth, "269 neighborhoods in 49 American Rust Belt cities have lost more than $50 \%$ of their housing since 1970" (2016: 3). In the years before the highly publicised 2013 municipal bankruptcy and subsequent restructuring, and before the 'turnaround' became visible, Detroit had been well known for its macabre urban condition often captured by 'ruin-porn' photographers, witnessed by urban explorers, desecrated by the unstoppable tide of 'scrappers', and avoided by many due to its stigmas as one of the most dangerous cities in America. Estimates put the number of abandoned or vacant properties in the range of $70,000-90,000$, from vacant lots to train stations, factories, churches, schools, hospitals, cultural venues, hotel and apartment buildings, and more single family houses than anyone knows what to do with (Fig. 4) (Detroit Works 2012: 272). This has created a semi-empty-city-condition, and along with the global financial crisis of 2008 and the largest municipal bankruptcy in the history of the USA in 2013, it set the stage for a massive land grab throughout the metro Detroit region as citizens faced foreclosures, and urban land and properties went to mass public auctions.

In recent years Detroit's downtown core has received increased positive media attention and has been called "resurgent", among many other optimistic monikers. Indeed, the condition that Detroit finds itself today is characteristic of bearing the scars of decentralisation explained in Mumford's 'fourth migration'. However, nearly 15 years after Fishman published "the Longer View", the narrative is changing in tangible ways and we see Detroit as becoming characteristic of a "turnaround", for the first time in decades, evidenced by recent additions to the latest census, a drop in violent crime, and signs in the central business district of what Fishman referred to as a hallmark of ReUrbanism "renewed vitality of the urban economy" (2005: 358). An example of this comes from the fact that between 2003 and 2016, downtown Detroit added just 902 residential units, while current demand (as of 2017) is projected for 1,400 units per year going forward, much of which is aimed at housing the current 80,000 employees in the downtown which currently houses only 6,444 people in 4,300 units (Larson 2017). In this paper, we delimit the discussion and case of Detroit to an area including and surrounding the downtown urban core, an area bound by: Interstate 75 to the south, to the east Woodward Avenue, to the north MLK Blvd/Mack Avenue, and to the west Grand River Avenue. What is distinctive of this identified area which fits into the discussion of re-weaving is the nature of the physical segregation and barriers caused by the extensive and interwoven system of interstates and freeways which all converge on the Downtown (I-75, M-10, I-375) which is situated between a key connection point between the rebirth of the Downtown and the ongoing more incremental improvement of Midtown (Fig. 5).

Several well-known and highly publicised projects, some planned, ongoing, and completed, can be found within the central zone of Detroit, accounting for billions of dollars in new investments. Considered on a district wide scale, this myriad of development activities aimed at 

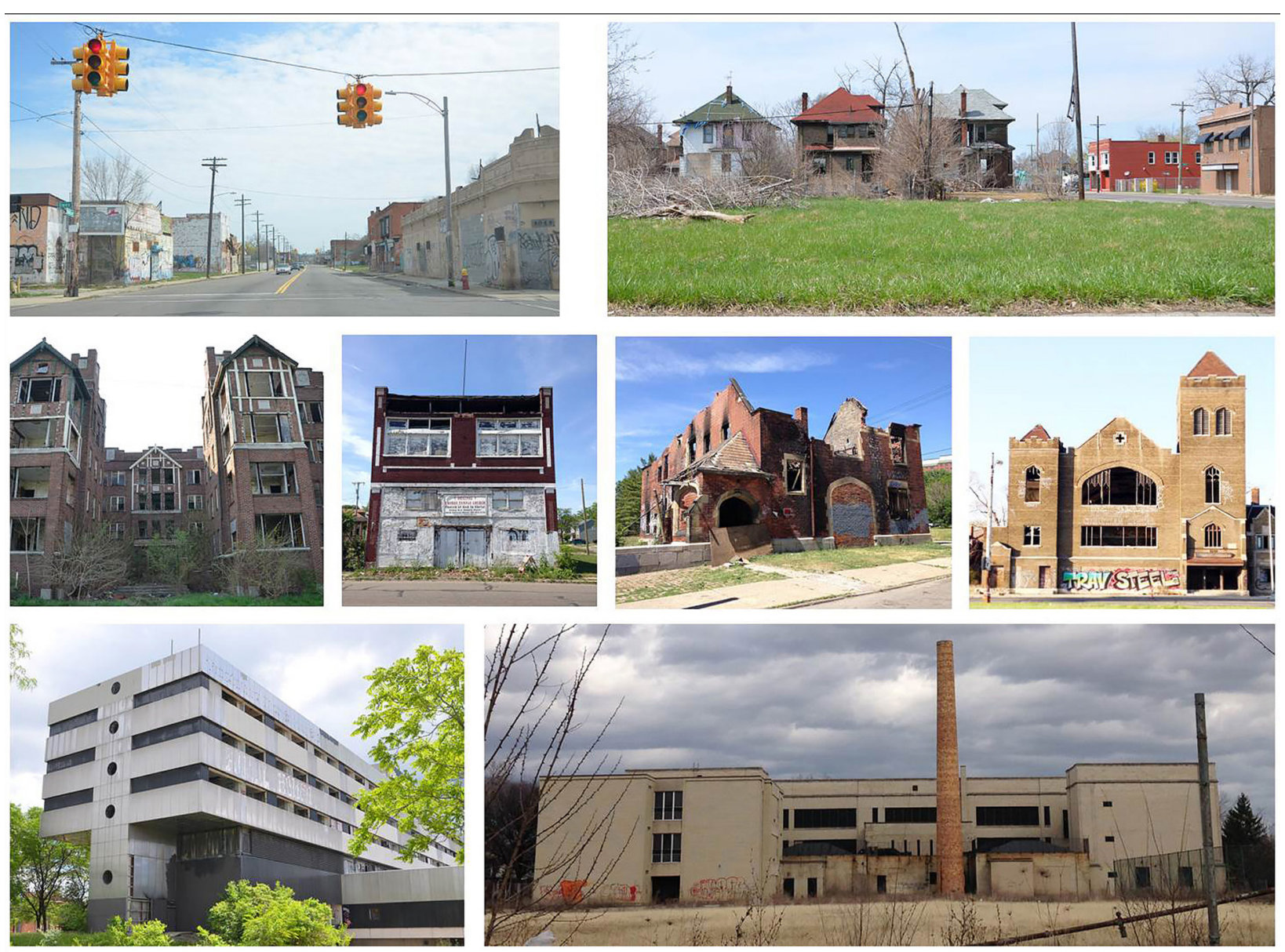

Fig. 5. Abandoned buildings and blighted landscapes showing the effects of the fourth migration. Images by authors.

rebuilding the city, including the rehabilitation of existing structures, construction of new structures, revitalisation of public places, and transit oriented solutions, taken together, exemplifies ReUrbanism. While many actors within the private and public sector converge in the rebuilding of Detroit, two well-known billionaire personalities and their associated corporations have been linked with the "Rebirth of Detroit". Dan Gilbert and his real estate firm Bedrock owns $60 \%$ of the land in Downtown Detroit, 90 properties in the urban core, and 1.4 million square meters (Larson 2017; Kiger 2018). North of the Downtown, in what was long known as the Lower Cass Corridor, the Ilitch family and their real estate firm, Olympia Development of Michigan dominate the map. This has created a situation of extremely concentrated land ownership by these two billionaires and their companies, who have largely become the new master-planners of post-bankruptcy Detroit. In effect, their visions for the city have become the gold standard due to two main reasons.
First, the Detroit city government was impoverished to the point of bankruptcy and desperate for investment and development, and second, democracy was suspended surrounding the bankruptcy as the state government appointed an Emergency Financial Manager who had sweeping powers over public restructuring and the ability to push what Jamie Peck terms "neoliberal austerity measures". This included a veto vote on anything the city council might vote against, thus who had the money made the rules and public input was of little importance (MLIVE 2014; Peck 2013; Peck 2016). It is in this climate that the most ambitious and sweeping redevelopment, "The District Detroit" has taken shape.

\section{Overview of The District Detroit}

We have focused on one of the most high profile urban developments in Detroit in decades, a large scale urban development known as "The 


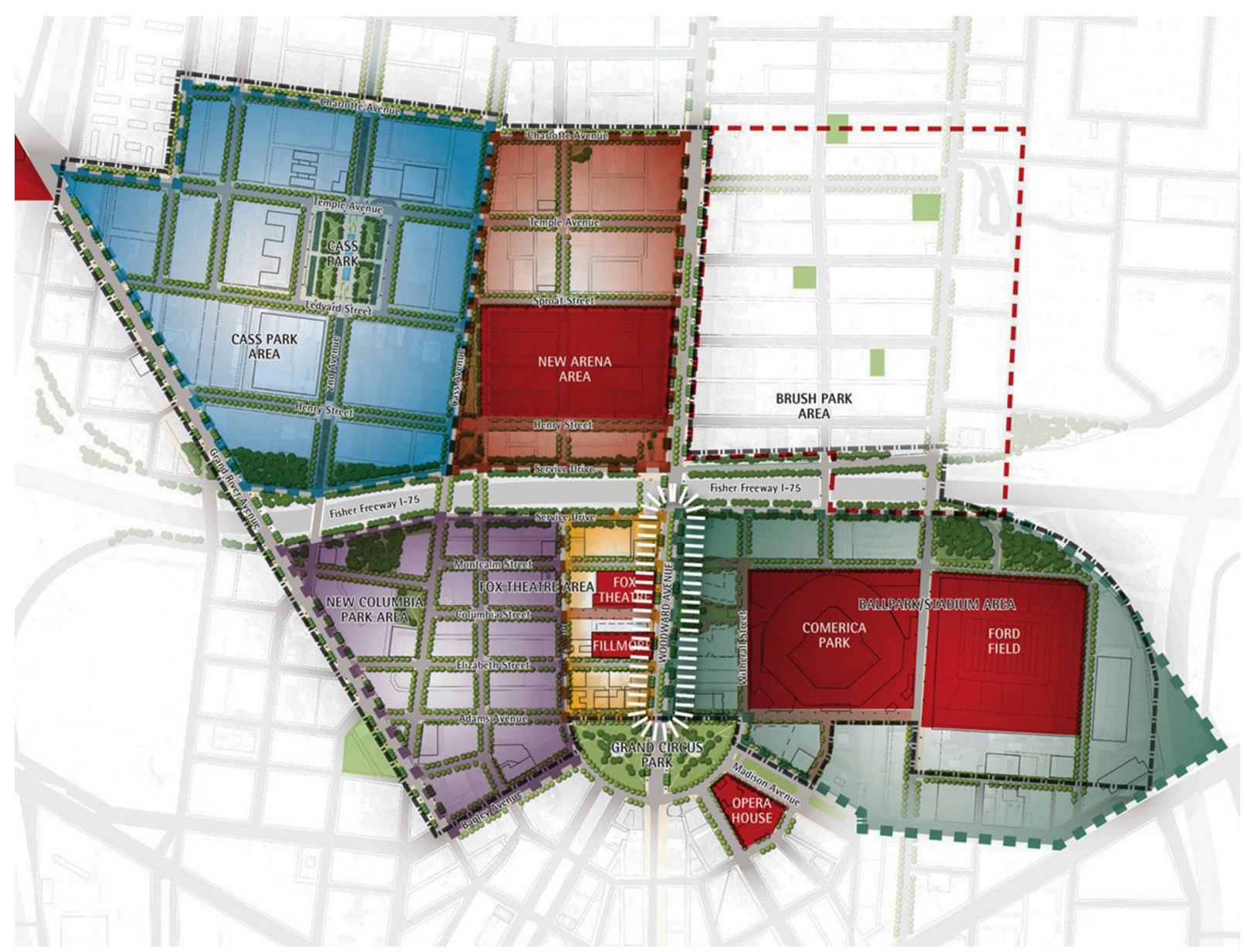

Fig. 6. Rendering of proposed District Detroit.

Courtesy: Olympia Development of Michigan.

District Detroit", a sports and entertainment district which promises to bring new residential, office, retail and restaurant space in addition to the construction of a new sports arena, already completed. The development is by the Ilitch family and their company, Olympia Development. Crain's Detroit Business Journal called it "a dramatic transformation in the heart of Detroit", with the headline: "the Ilitch family breaks ground on a \$450 million dollar arena with another \$200 million in apartments, restaurants, office buildings, parks and shops over 45 blocks. This is the city's entertainment district, super-sized" (Shea 2014a). By the time the arena was completed in 2017 , the cost had nearly doubled to $\$ 863$ million. President and CEO Chris Ilitch described Detroit as "an investor's playground" and proclaimed "this project takes on a much bigger scale. There is nothing like this going on in our country" (Shea 2014a). Overall, the developer refers to it as an investment of $\$ 1.4$ billion to act as a "driving catalyst of the city's remarkable resurgence"
(The District Detroit 2018). Ilitch also noted that the expectation is that the development will be attractive to millennials who want to live in the city, where apartment demand currently outstrips the supply. As the President of Midtown Detroit Inc. Susan Mosey said, "it takes a very long time to rebuild the fabric of a place, density is the driver, as we have more people living here, the business folks are naturally attracted to these areas, and the momentum builds" (Cowley 2015). But in the case of the District, the timeline for the project could not be considered incremental in any sense, and the developer has described their intention to build the arena and the mixed-use developments around it in the 45-50 block area all at once, within an immediate time frame to act as a catalyst for the city and will also include a transit stop on the new M-1 Rail tram line, which Olympia has also invested heavily in (Shea 2014a). One of the overall goals of the project is connecting the Downtown to Midtown Detroit into one vibrant area (Fig. 6). 
The economic and political conditions for this redevelopment to take place is what journalist Bill Shea called "a study in the marriage of timing, politics, money, influence" which spanned decades of land acquisitions, significant changes in local political regimes and the duality of the global financial recession and the Detroit municipal bankruptcy (Shea 2017). The funding for this project relies on a 2013 agreement between Detroit's Downtown Development Authority (DDA) and Olympia Development and involves a mixture of private and public financing, with the developer paying $62 \%$ of the costs (\$539 million) with \$324 million in public funds (Detroit News 2017). The public financing led by the DDA comes in the form of a series of bonds with no money being spent from the city general taxes fund (Shea 2014b). The developer describes the economic impacts as including: 8,300 construction jobs, 1,100 permanent post-construction jobs, and a $\$ 1.8$ billion economic impact (Shea 2014a). While the developers have noted that they are doing this both for Detroit and as a family passion project and long held dream, they have also acknowledged in the local media their role as a private developer acting as a city planner in the unique climate of post-bankruptcy Detroit. Olympia has stated that they will spend "tens of millions" to fill a void usually undertaken by a government to improve the infrastructure in the project area including: roads, street lighting, landscaping, and public space rehabilitation, which according to Ilitch, "frees the city up to spend its resources on other priorities" (Shea 2014a), bringing into question the role of the state and the structuring of private capital in city planning.

Some of the key elements of the project are listed below (Shea 2014a; The District Detroit 2018):

- 50 blocks over 12 acres and five neighbourhoods, over $\$ 2$ billion in investment by Olympia Development.

- Little Caesars Arena, multi-purpose, seating for 20,000, final cost $\$ 863$ million.

- State-Of-The-Art Sports Medicine Institute, $\$ 65$ million development, five-storey, 127,000 square feet, including mixed-use street-level office and retail.

- Adoption and rehabilitation of city-owned Cass Park included within the development area, including focus on creating further public spaces.
- \$30 million Temple West multi-storey mixeduse building, 285,000 square feet, 3,600 square feet of retail space, 730 parking spaces.

- Ilitch owned Little Caesars pizza company headquarters, 240,000 square feet, nine storeys.

- Affordable housing promised in several rehabilitated historic properties and in new developments.

\section{Critical considerations}

The leader of the Ilitch business organisation and the mayor of Detroit have both made broad claims and promises regarding the new development. The CEO of Ilitch Holdings Inc. has promised that "The District Detroit will be one of the most exciting places in the country to live," and that the new developments will be "in the heart of the action, in a city on the rise" (Cision 2017). Detroit mayor Duggan has lauded the inclusion of preserving historic buildings and adding affordable housing into the redevelopment plan: “Olympia Development's plan to preserve several historic buildings and bring hundreds of new residential units into the heart of the city is a clear sign of the demand for housing in Detroit. The fact that they are including nearly 140 units of new affordable housing across these six developments aligns perfectly with our efforts to build a city that includes everyone" (Detroit Free Press 2018). But moving beyond the claims of the developer and civic leaders, which are typically meant to self-promote the benefits of their project, it is important to consider the position taken by Susan Fainstein who has commented on the spatial dimensions of justice and the triumph of neoliberalism in regards to urban development. Often in contemporary urban planning and development, economic development has become the first priority, instead of planning, equity, diversity and democracy. Making cities 'nice' by adding urban amenities such as landscaped parks, increased retail and gastronomy services, and beauty, is not equal to making cities "just" (Fainstein 2018). Considering the diverse populations that all cities hold, with diverse needs, there is no single answer. ReUrbanism is not positioned in this paper as an ideal or utopian paradigm, rather we have attempted to carve 

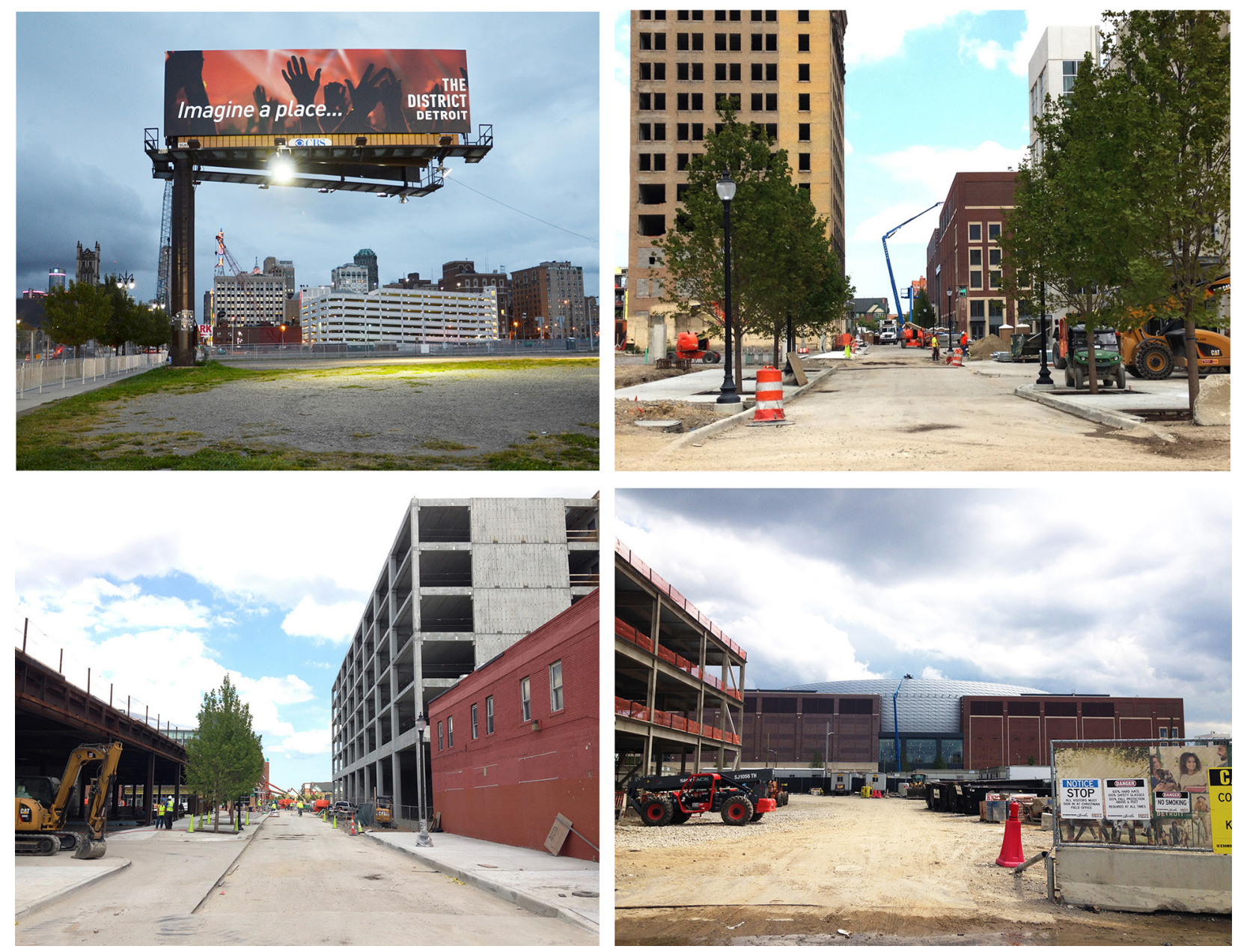

Fig. 7. The District Detroit takes shape, top left March 2014, all other images August 2017. Photos by authors.

out space in the urban-isms to reintroduce and redefine this in order to allow for the naming of this type of global urban development, which can open the road to more dialogue and critical analysis of these types that fall within this definition. Perhaps at best this case and others like it can represent the aspirations and principled hopes of a redevelopment, as well as offer inquiry into the questionable claims of an intervention that accepts the neo-liberal conditions of contemporary urban planning practice.

The deindustrialisation of urban landscapes across the globe, including the emblematic case of Detroit has brought both a decrease and increase in negative qualities. Heavy industrial pollution and the array of ills associated with urban industry may decline, while side effects such as crime and unemployment increase. Detroit and other cities lagging economically from the effect of the loss of traditional capital investment (factories, jobs) are then left to grapple with the question of how to attract people to live in a place that could be deemed unattractive for a myriad of reasons. Do ReUrbanist style developments offer a piece of the solution by creating new opportunities within the urban landscape including affordable housing, employment, and places to recreate? Post-industrial decay has disrupted the urban fabric and projects such as this one, offering a solution as part of a broader effort to reweave the urban fabric and fill in the gaps. One key question though is: is this 'urbanism' or is this one big architectural project?

In concluding this section, we return to what Fishman wrote that the disadvantages of the 'fourth migration' (dense, walkable cities, with older housing stock and retail) had become the advantages of the 'fifth migration', or 'reurbanisation', which Fishman called "crucially dependent on the recovery of the elite down-town office and residential districts" (2005: 358-359). With Detroit's civic and business leaders encouraging 
a strong focus on reintroducing the idea of not only working, but also living in the central city to populations who had long lived outside the centre, or had never lived beyond the suburbs, this project and others in the downtown core are common in contributing to a focus on building "place" in the downtown. It's as though the major players in Detroit's ongoing revitalisation have read Fishman's quotes: "No office park can match the aura of a high floor of a skyscraper located at a region's historic core", and "suburbs were able to duplicate almost all the urban functions that once defined the central city, but they were unable to duplicate the urban experience itself" (2005: 361-363). In Detroit through the case of The District Detroit, we see that the focus in city-planning and development through a partnership of public and private financing is upon creating urban experience, and increasing density. As Fishman writes, "planning the fifth migration thus means in large part the imaginative recovery and reuse of the strengths of a sadly depleted urban fabric" (2005: 363), nowhere is this urban fabric more depleted, or more in need of recovery, reuse, repair - reweaving - than in the Detroit of the bankruptcy era, where already major advancements have been made in the recovery of the downtown urban landscape.

\section{Discussion and reflections}

The heart of the ReUrbanism urban planning and design interventions, manifested alongside Detroit through the global contemporary examples of Stockholm, London, Washington DC and other inner cities is: reknitting the disjoined urban fabric, creating new residential/mixed use neighbourhoods around new designed public spaces and redesigning and planning major roads in order to produce integrated streets and boulevards. All of this might seem simple as a result but it involves in many places an extremely complex and intricate planning, urban sensitivity and historical cognition to reweave the overall public space and the built environment landscape into a new, unified framework. This paradigm is composed and shaped of fundamentally constant spatial and formal elements of urbanism.

Some years back, Barnett (2011) presented the 'emerging phenomenon of multiple urbanisms' by listing the sixty newest urbanisms and dividing them into six categories - Systems Urbanisms, Green Urbanisms, Traditional Urbanisms, Community Urbanisms, Socio-political Urbanisms, and Headline Urbanisms, and briefly described what they were about. Barnett concluded the article by asking, "Why so many urbanisms?" and stated "If every discernible characteristic of cities is given its own category, the process negates itself" and that "most urbanisms are actually about preserving the environment, traditional city design, urban systems, community participation, or the politics of urban change. But these categories are not mutually exclusive" (Barnett 2011: 21). As Dongsei writes, "nevertheless, this view tends to coalesce and homogenise the vastly diverse urbanisms into one univocal overlapping form of urbanism" (Dongsei 2014). Urbanism paradigms can be seen and treated as a standard, perspective, or set of ideas in architecture, urban planning and design. Simply they are a way of looking at the urban fabric of the city in a contemporary manner employing a set of ideas, tools, approaches, design theories and ideologies. The ReUrbanism trend/ideal/paradigm is presented in a taxonomic table juxtaposed to six selected elements of urban planning and design (Table 2).

ReUrbanism as Peterson observes (in Strickland 2005), addressees the larger patterns of the city, the neighbourhoods and the public spaces. It is jointly serving as the context and the enabler of architecture. In a sense this is a vision, as well as a case for "The $4^{\text {th }}$ Place and/or $4^{\text {th }}$ Urbanism" - the ultimate mixed-use environment that includes the home, places of work, and the great Third Places described by Oldenburg (1989). The $4^{\text {th }}$ Place is the confluence of all the key elements in our daily lives and more, allowing us to live, work, learn, and play together in one place. ReUrbanism accepts the premise and necessity of tall buildings and very high density as an urban typology, as well as an urban reality with a place-making that is seen as a humanistic approach with comprehension of the reality on the ground. That is coupled by the reparation of the grid and network of streets, mixed use, through complex and intricate planning in many spaces to reweave the urban pattern and especially that of public spaces. The architecture of buildings provides a drop here, a sort of scenery 
Table 2. ReUrbanism reflected via urbanism components of context, process and design as well as aspects of space, place and revival.

\begin{tabular}{|l|l|}
\hline Six elements & \multicolumn{1}{|c|}{ ReUrbanism } \\
\hline context & $\begin{array}{l}\text { The city is seen as constant urban fabric with existing building stock that produces density and stable } \\
\text { conditions throughout the space enabling a complex set of public and private spaces for diversity to } \\
\text { occur with distinct objects and places. }\end{array}$ \\
\hline process & $\begin{array}{l}\text { Classical approach with urban-master planning from above and with a certain number of civic in- } \\
\text { volvement elements in terms of alternatives. Strong sense for the developers and the city structure as } \\
\text { a whole and market - real estate forces that guide it. }\end{array}$ \\
\hline design & $\begin{array}{l}\text { Urban revival and regeneration fabric constructs in terms of compositions and ensembles and solidi- } \\
\text { fication of urban planning and design procedures. Contemporary urban design and architecture with } \\
\text { historical precedents and modern contextualisation. }\end{array}$ \\
\hline space & $\begin{array}{l}\text { Understanding of cities as parts of spatial structure with their anchored dimension through sequence } \\
\text { of places and ensembles. }\end{array}$ \\
\hline place & $\begin{array}{l}\text { Leaning on the existing elements of fabric and place formation to adapt to the stable forms and densi- } \\
\text { ty of the present. }\end{array}$ \\
\hline revival & $\begin{array}{l}\text { Adapting to and healing of existing urban environments. Restoration and interpretation through } \\
\text { re-weaving of urban form. }\end{array}$ \\
\hline
\end{tabular}

Source: own study.

for this type of urbanism but not at all a dominating element, but more as a complimentary one. In the heart of it there is the element of temporal and historic continuity assembled in a bricolage of different architectures in a recognisable grid and pattern. To think in historical categories doesn't mean that we need to recreate some of the historical phases or aspects (New Urbanism), but more that we really need to understand the present as offspring that has grown from historical roots (ReUrbanism). The differences which are created from individualistic artistic tendencies of master builders and planners to 'build and compose' the city in their own, unique way, give a necessary ingredient of individual originality, much so needed in urbanism, is combined in ReUrbanism by market forces, high density and real estate principles.

Re-Urbanism's approach to an urban form as a tissue that needs to be re-patched and re-woven is both a social and urban issue of spatial continuity. In ReUrbanism, spatial continuity is an urban issue, but it occurs almost entirely at the architectural scale. Whether a building is adapted over time or torn down is heavily influenced by its design and market forces. As buildings age, the conditions they serve evolve, and the shelf life of a building is tied to how easily it can adapt to new requirements. At a social scale, spatial continuity allows the built fabric of a place to act as a cultural memory aid, a transitional bridging element towards the present and the future forcibly uniting the current inhabitants of a place with those who came before. As our most permanent cultural artefacts, buildings and the spaces around them act as a reasonably solid environment for the activities that comprise our lives.

ReUrbanism master planners and urban designers give shape and form to our city blocks, districts, and neighbourhoods. They articulate urban plans in three dimensions and establish forms, codes, rules, guidelines, and frameworks for (sensitive) architects and (sensible) developers to follow. These individuals occupy an important role in the development and redevelopment of our cities and draw simultaneously on the analysis and policy roles of urban planners and the form-giving aspects of architects engaging the totality of design and planning, and serve as the critical, catalytic link across disciplines and professions. Krieger (2009) makes a refined reflection when he says that the urban designers can at times find themselves in dire straits, for example, trapped between two societal expectations: to remain the guardians of history (what is best about traditional urbanism), yet also help mastermind our collective urban futures by creatively responding to contemporary conditions.

Kelbaugh attributes the transformation of American urban cores in recent decades to a type of urbanism which in his words is not "self-conscious" but is a result of urban developers responding to market forces, he describes this "market urbanism" as a type of urban 
development that results from "current conventions and modes of land acquisition, professional planning and design services, government regulation, financing, and construction for the thousands of real estate development projects that spring up in places and at times determined by macro and micro market forces and by the decisions of private developers" (2007: 12). This poses the question if ReUrbanism is equitable within this market urbanism crescendo scheme? This seems unlikely given the heavy emphasis on responding to market demands. The new economic geography of contemporary urban regeneration schemes may be yet another urban reflection of the contemporary reality: neoliberal urban policy and market driven urban planning and design gets its strongest proponent and materialisation in ReUrbanism. As New Urbanism might be accused of being a new communitarian trap (Harvey 2001) for its residents, and that Everyday Urbanism (Chase et al. 2008) is the prisoner of its overestimation of the power of the common place, while Post Urbanism persists in its fantasies, its ideology, its pretension (Koolhaas 1994), creating worlds of abstract architectural language devoured of any physical context and human scale, the ReUrbanism in its cynical, almost machine-like urban approach of perfectness within the context of a global capitalist political economy does the opposite. It creates a perfect world, but neither futuristic, nor nostalgic utopian, nor communal open society one. It creates an urbanism that is bounded by the rules of the markets, regulations, ordinances, but also by reality. In that new reality, affordability and planning of a just, equitable, diverse, equal, and hopeful city of opportunities simply does not exist nor can have space to exist in the current state.

ReUrbanism style developments often do not guarantee opportunity for all through equal access to housing, transportation and public space as that is not the logic of contemporary urban economics, real-estate development, city strategic planning and regeneration schemes where there is a massive reduction in commitment to social or affordable housing and consequently much more price setting by the market which all slowly but surely lead to gentrification. ReUrbanism responds well to triumph of neo-liberalism in urban policy and planning (Fainstein 2009). Yet, over the past three decades the ideological triumph of neoliberalism has caused the allocation of spatial, political, economic, and financial resources to favour economic growth at the expense of wider social benefits (Fainstein 2010). ReUrbanism projects have been and are the poster child of that.

\section{Conclusions}

The paper examined how some of the fundamental values of ReUrbanism contribute to the larger urbanism discourse, through the specific Detroit case-study reflection. First, the analysis of ReUrbanism can help us provide a framework that in turn can assist in the sound critique of current urban conditions and existing conceptual frameworks that lead to new choices and designs as well as new theoretical innovations. Second, the ReUrbanism is a great example and an excellent representation of the urban evolution associated with new economic geographies and cities being densified by market approaches and fuelled by neo-liberal policies. Third, it has to do with the pluralism inherent in the notion of urbanism and the vocabulary and syntax that this approach brings, making it separate and rather distinct from New and Post Urbanism. Forth, it brings clarity to the table when one illustrates projects and the tenets they stand for making it easier to understand the reformative changes on the ground it later makes. Finally, ReUrbanism is the good histrionics of a healthy evolution of thought in the larger urbanism discourse that makes itself relevant and virile for the current period and stakeholder they operate for.

Child's (2006) idea that urban planners and designers must analyse and subsequently adopt the community's civitas (its goals and reasons for coming together), genius loci (how it best interacts with its context and landscape), and urbanitas (its traditions of a built form) loosely flows within ReUrbanism, but it flows in the particulars and universals of its principles. The city and its relatives are in the constant interplay between the particular and the universal. It is a field for theories to battle at any scale, whether it is that of a park or that of a region. As Douglas Kelbaugh noted while he was moderating the Michigan Debates, the series gave birth to new types of "urbanism". He attributed this to the complexity that is inherent when discussing a subject such 
as the city. Cities are guided by (complexity and contradiction) urbanisms with all varieties of suffixes and prefixes, each one bringing a different understanding to the organised complexity that is a city. The most valuable "next" idea will be the one that continues to meld different thoughts and observations into a more integrated urban theory (Giometti 2006). As Carmona (2010) notes rightly, in the future, the quest for sustainable place-making may surpass all these (New, Post, Everyday, Re) urbanisms. There are desirable (generic) principles of good urbanism and of place-making, but their application is tempered by and contingent upon the realities of the local situation. The aim of this place-making quest should be to engage with ideas while avoiding being distracted by ideology and ideologues through an urban problem-solving process. There are desirable principles of good urbanism and of place-making, but their application is tempered by and contingent upon the realities of the local situation (Carmona et al. 2010: 43-46).

\section{References}

Barnett J., 2011. City design: Modernist, traditional, green and systems perspectives. Routledge, London.

Bitter C., Krause A., 2012. Re-urbanism or bigger 'burbs'?: The implications of demographic change for housing markets. Runstad Center for Real Estate Studies, Department of Urban Design and Planning (working draft research paper), University of Washington.

Carmona M., Heath T., Oc T., Tiesdell S., 2010. Public places, urban spaces. Elsevier/ Architectural Press. Boston, MA.

Chase J., Crawford M., Kaliski J., 2008. Everyday urbanism expanded. Monacelli Press, New York.

Childs M., 2006. Squares: A public place design guide for urbanists. The University of New Mexico Press, Albuquerque.

Cision, 2017. The District Detroit announces Detroit's largest residential development initiative in more than 20 years. PR Newswire, 26 May 2017. Online: https://www. prnewswire.com/news-releases/the-district-detroit-announces-detroits-largest-residential-development-initiative-in-more-than-20-years-300464634.html (accessed: 22 July 2018).

Cowan R., Campbell K., 2002 Re:urbanism - A challenge to the urban summit. Exchange, London.

Cowley S., 2015. How Wayne state police helped breathe life into a blighted Detroit strip. The New York Times, 25 February 2015. Online: https://www.nytimes. com/2015/02/26/business/smallbusiness/howwayne-state-police-helped-breathe-life-into-a-blighteddetroit-strip.html?_r=3 (accessed: 25 July 2018).

Cuthbert A., 2006. The form of cities. Blackwell Publishing, Oxford.

Detroit Free Press, 2018. Is new 20-story residential high-rise coming to Comerica Park? Crain's says yes. Detroit Free
Press, 30 January 2018. Online: https://eu.freep.com/ story/news/local/michigan/detroit/2018/01/29/comerica-park-apartments/1076121001/ (accessed: 22 July 2018).

Detroit News, 2017. Little Caesars Arena's funding mix not withoutcritics. Detroit News. Online: http:/ / www.detroitnews.com/story/news/local/detroit-city/2017/10/04/ little-caesars-arena-financing/106313428/ (accessed: 10 June 2017).

Detroit Works, 2012. Detroit future city: Detroit strategic framework plan. Inland Press, Detroit.

Dongsei K., 2014. Learning from adjectival urbanisms: The pluralistic. In: Stuart J., Wilson M. (eds), $102^{\text {nd }}$ ACSA annual meeting proceedings. Globalizing architecture/Flows and disruptions.

Fainstein S., 2000. New directions in planning theory. Urban Affairs Review 35(4).

Fainstein S., 2009. Planning and the just city. In: Marcuse P., Connolly J., Novy J.,

Olivo I., Potter C., Steil J. (eds), Searching for the just city: Debates in urban theory and practice. Routledge, London: 144-58.

Fainstein S., 2010. The just city. Cornell University Press, Ithaca.

Fainstein S., 2018. Lecture: The just city (lecture notes). The Royal Institute of Technology, Stockholm (delivered 23 May 2018).

Fraker H., 2007. Where is the urban design discourse? (rally discussion). Places (Design Observer) 19(3). College of Environmental Design, UC Berkeley.

Gehl J., 2010. Cities for people. Island Press, Washington DC.

Giometti C., 2006 Integrating urbanisms: Growing places between new urbanism and post-urbanism. In Cheng R., Tripeny P. (eds), Getting real: Design ethos now. 94 ${ }^{\text {th }}$ Annual meeting of Collegiate Schools of Architecture. Salt Lake City, Utah: 269-275.

Haas T., Olsson K., 2014. Transmutation and reinvention of public spaces through ideals of urban planning and design. Space and Culture 17(1): 59-68.

Hackworth J., 2016. Demolition as urban policy in the American Rust Belt. Environment and planning A: Economy and Space 48(11): 2201-2222.

Harvey D., 2001. The new urbanism and the communitarian trap (on social problems and the false hope of design). Harvard Design Magazine, Winter/Spring 1997, No. 1. President and Fellows of Harvard College and The MIT Press: 1-3.

Kelbaugh D., 2007. Toward an integrated paradigm: Further thoughts on the three urbanisms. Places (Design Observer) 19(2). College of Environmental Design, UC Berkeley.

Kiger J., 2018. Developers Ilitch and Gilbert describe their roles in Detroit's revival (WWW document) Urban Land Magazine. Online: https://urbanland.uli.org/development-business/developers-chris-ilitch-dan-gilbert-describe-roles-detroits-revival/ (accessed: 3 May 2018).

Koolhaas R., 1994. What ever happened to urbanism? In: Jenks C., Kropf K. (eds), Theories and manifestos of contemporary architecture. Academy editions, 1997. Chichester, West Sussex.

Koolhaas R., 2007. In search of authenticity. In Burdett R., Deyan S. (eds), The endless city. Phaidon, London: 320323. 
Kotkin J., 2007. Opportunity urbanism: An emerging paradigm for the $21^{\text {st }}$ century (research report by Joel Kotkin), Joel Kotkin and the Greater Houston Partnership, Houston.

Krieger A., 2006. Territories of urban design. In: Rowland J., Moor M. (eds), Urban design futures, Routledge, London: 18-29.

Krieger A., 2009. Being urban minded: Three current debates around urban design practice. Planetizen: Urban Planning, Design and Development. Online: https://www.planetizen.com/node/37553 (accessed: 4 April 2017).

Larson E., 2017. Downtown Detroit partnership. (PowerPoint presentation). ICSC, Michigan Continuing Education Program. Online: https://www.slideshare.net/DowntownDetroitPartnership/icsc-2017-michigan-continuing-education-program-eric-larson-downtown-detroit-partnership (accessed: 7 June 2018).

Mahy M., Alexander C., Neis H., Anninou A., King I., 1987. A new theory of urban design. Oxford University Press, New York.

Neill W.J., 2015. Carry on shrinking?: The bankruptcy of urban policy in Detroit. Planning Practice and Research 30(1): $1-14$.

Oldenburg R., 1989. The great good place. Paragon House, New York.

Peck J., 2013. Pushing austerity: State failure, municipal bankruptcy and the crises of fiscal federalism in the USA. Cambridge Journal of Regions, Economy and Society: 24-28.

Peck J., 2016. Economic rationality meets celebrity urbanology: Exploring Edward Glaeser's city. International Journal of Urban and Regional Research 40(1): 1-30.

Peterson S., Littenberg B., 2005. On ReUrbanism. In: Strickland R. (ed.), Post urbanism and ReUrbanism. Arts Press, New York (Michigan Debates on urbanism book III, The
Regents of the University of Michigan, Series Editor: Douglas Kelbaugh).

Ryan B., 2017. The largest art: A measured manifesto for a plural urbanism. The MIT Press, Cambridge.

Schwarzer M., 2000. The contemporary city in four movements. Journal of Urban Design 5(2): 127-144.

Shea B., 2014. Detroit Rink City: Illitches' grand plan to supersize the entertainment district. Crain's Detroit Business Journal, 20 July 2014. Online: http:/ / www.crainsdetroit. com/article/20140720/news03/140719845/detroit-rinkcity-ilitches-grand-plan-to-supersize-the (accessed: 2 July 2018).

Shea B., 2014b. On cost, financing of Wings arena: Here are answers. Crain's Detroit Business Journal, 21 September 2014. Online: http://www.crainsdetroit.com/ article/20140921/NEWS/309219990/on-cost-financingof-wings-arena-here-are-answers (accessed: 7 December 2018).

Shea B., 2017. How Olympia financed an arena in a bankrupt city. Crain's Detroit Business Journal, 10 September 2017. Online: http://www.crainsdetroit.com/article/20170910/news/638626/how-olympia-financed-anarena-in-a-bankrupt-city (accessed: 2 July 2018).

Talen E., 2005. New urbanism \& American planning: The conflict of cultures. Routledge, New York.

The District Detroit, 2018. Online: http://www.districtdetroit.com/press-releases/new-parking-amenities-offered-in-the-district-detroit (accessed: 20 July 2018).

Wiechmann T., Pallagst K.M., 2012. Urban shrinkage in Germany and the USA: A comparison of transformation patterns and local strategies. International Journal of Urban and Regional Research 36(2): 261-280. 